ABDI: Jurnal Pengabdian dan Pemberdayaan Masyarakat ISSN: 2656-369X (Print), 2684-8570 (Online)

Volume 1 No. 2, Desember 2019

http://abdi.ppj.unp.ac.id/index.php/abdi

Email: abdi@ppj.unp.ac.id

DOI: https://doi.org/10.24036/abdi.vli2.31

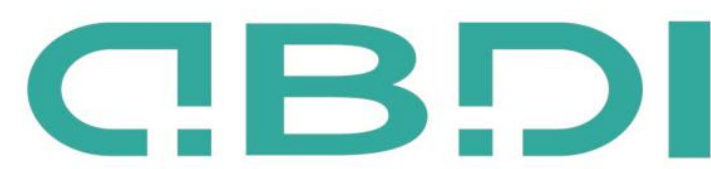

ABDI: JURNAL PENGABDIAN DAN PEMBERDAYAAN MASYARAKAT

\title{
Optimalisasi Kompetensi Guru Sekolah Luar Biasa Dengan Penerapan Teknik Manual Brewing dalam Penyeduhan Kopi
}

\author{
Rila Muspita ${ }^{1}$, Elsa Efrina ${ }^{2}$, Reno Fernandes ${ }^{3}$, AB Sarca Putera ${ }^{4}$, Arisul Mahdi ${ }^{5}$ \\ 1,2,5 Jurusan Pendidikan Luar Biasa Universitas Negeri Padang \\ ${ }^{3}$ Jurusan Sosiologi Universitas Negeri Padang \\ ${ }^{4}$ Jurusan Sosiologi Universitas Negeri Padang
}

E-mail: rilamuspita@fip.unp.ac.id, elsaefrina@ fip.unp.ac.id, renofernandes@fis.unp.ac.id, absarcaputera@ fis.unp.ac.id arisulmahdi@fip.unp.ac.id

\begin{abstract}
Abstrak
Kajian ini membahas tentang mengoptimalkan kompetensi guru dalam mengembangkan peserta didik untuk mengaktualisasikan diri yang meliputi memfasilitasi peserta didik mengembangkan berbagai potensi akademik maupun non-akademik. Potensi non-akademik dapat berupa soft skill untuk terjun ke dunia usaha sehingga dapat mandiri sesuai dengan cita-cita bangsa. Pelaksanaan dilakukan dua tahapan yaitu tahapan pertama pemberian materi yang dalam bentuk seminar satu hari dan dilanjutkan dengan pelatihan selama enam kali. Guruguru diberikan pre-test dan post-test untuk melihat kemampuan awal dan sebagai evaluasi kemampuan guru sebelum dan sesudah pemberian materi dan pelatihan. Melalui pelatihan ini guru-guru memiliki kemampuan dalam menyeduh kopi dengan menerapkan teknik manual brewing. Sehingga soft skill yang dimiliki guru akan ditransfer kepada anak hambatan pendengaran pada mata pelajaran tataboga atau vocasional. Penerapan teknik manual brewing dalam penyeduhan kopi dirasa perlu diberikan kepada guru-guru agara dapat dipraktekkan lansung dan dimasukkan sebagai bahan ajar karena keberadaan penyandang disabilitas di Kota Padang khususnya dan Sumatera Barat pada umumnya berada pada lingkungan yang memiliki kekayaan kearifan lokal. Salah satu yang memiliki pasar yang cukup luas dan peminat yang terus-menerus adalah minuman kopi. Penyajian kopi yang terus digemari konsumen adalah dengan teknik manual brewing karena teknik ini memiliki keunikan tersendiri menciptakan cita rasa keaslian kopi itu sendiri. Sehingga hal ini akan menjadi peluang bagi anak hambatan pendengaran untuk bekerja dan bahkan membuka usaha sendiri.
\end{abstract}

Kata kunci: Kompetensi guru, Kopi, Manual brewing, Penyandang disabilitas

\section{Abstract}

This study discusses optimizing teacher competencies in developing students to actualize themselves, which includes facilitating students to develop various academic and non-academic potentials. Non-academic potential can be in the form of soft skills to enter the business world so that they can be independent by the ideals of the nation. The implementation was carried out in two stages, namely the first stage of giving the material in the form of a one-day seminar and continued with training six times. Teachers are given pre-test and post-test to see the initial ability and as an evaluation of the knowledge of teachers before and after the provision of material and training. Through this training, the teachers can brew coffee by applying manual brewing techniques. So that soft skills possessed by the teacher will be transferred to children with hearing impairment in hopefully or vocational subjects. The application of manual brewing techniques in the brewing of coffee is deemed necessary to give to teachers so that it can be practiced directly and included as teaching material because the existence of persons with disabilities in the city of Padang in particular and West Sumatra, in general, is in an environment that has a wealth of local wisdom. One that has a reasonably broad market and a constant interest is coffee drinks. The presentation of coffee that continues to be favored by consumers is by manual brewing technique because this technique has its uniqueness to create a taste of the authenticity of the coffee itself. So this will be an opportunity for hearing impaired children's work and even open their businesses.

Keywords: Coffee, Manual brewing, Persons with disabilities, Teacher competency

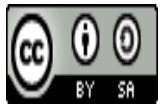

Received: 5 Desember $2019 \quad$ Revised: 12 Desember $2019 \quad$ Available Online: 16 Desember 2019 


\section{Pendahuluan}

Guru seyogyanya memiliki beberapa kopetensi sebagaimana menurut Undang-Undang Nomor 14 Tahun 2005 pasal 10 ayat (1) "Kompetensi guru sebagaimana dimaksud dalam Pasal 8 meliputi kompetensi pedagogik, kompetensi kepribadian, kompetensi sosial, dan kompetensi profesional yang diperoleh melalui pendidikan profesi. Kompetensi yang berhubungan lansung dengan peserta didik adalah kompetensi pedagogik dimana guru dituntut untuk dapat memahami peserta didik, perancangan pembelajaran, melaksanakan pembelajaran, merancang dan melaksanakan evaluasi pembelajaran, dan mengembangkan peserta didik untuk mengaktualisasikan berbagai potensinya.

Diantara kompetensi pedagogik yang krisis adalah kompetensi guru dalam mengembangkan peserta didik untuk mengaktualisasikan diri yang meliputi memfasilitasi peserta didik mengembangkan berbagai potensi akademik maupun nonakademik. Potensi non-akademik dapat berupa mampunya anak untuk terjun ke dunia usaha sehingga dapat mandiri sesuai dengan cita-cita bangsa yang tertuang dalam Undang-Undang Dasar. Selain itu guru harus memiliki kompetensi untuk mencapai target terealisasinya kurikulum 2013. Dimana paling sedikitnya menanamkan 5 karakter penting yang harus dimiliki oleh siswa yakni karakter religius, nasionalis, integritas, gotong royong, dan mandiri.

Sebagai guru sekolah luar biasa, guru harus mampu mengembangkan potensi penyandang disabilitas salah satunya anak hambatan pendengaran. Karena diantara 5 karakter yang disebutkan di atas titik fokus untuk penyandang disabilitas adalah mengenai karakter kemadirian. Karakter kemandirian dapat dibentuk salah satunya memberikan soft skill bagi anak hambatan pendengaran agar dapat mebuka usaha sendiri. Sebagaimana menurut Muspita, R., Safaruddin, S., Ardisal, A., \& Sopandi, A. A. (2018) salah satu penyandang disabilitas yang memungkinkan membuka usaha secara professional terkhusus dalam bidang tata boga adalah anak dengan hambatan pendengaran.

Soft skill yang akan dibahas pada materi pelajaran tataboga yaitu beverage. Salah satu beverage yang diminati berkelanjutan adalah minuman kopi. Minuman kopi digolongkan dalam salah satu minuman perangsang. Salah satu keuntungan kopi adalah sebagai perangsang dalam melakukan aktivitas (Hastuti, D. S., 2018).

Pada umumnya kajian tentang kopi banyak ditemukan hanya pada kajian industri dan belum masuk sebagai kajian dalam dunia pendidikan. Sebagaimana pemaparan dari Perkasa, A. G. (2018) tentang program Specialty Coffee Association yang berhubungan dengan kesejahteraan petani kopi di Aceh Pantan Musara. Kajian ini menunjukkan bahwa dengan adanya program Specialty Coffee Association yaitu World Coffee Event pada tahun 2017 membuat harga jual kopi dengan brand kopi specialty Aceh. Selanjutnya Triatmoko, E., Fitriadi, S., \& Gafur, A. (2016) dalam kajiannnya menyatakan bahwa masalah yang dihadapi pengusaha kopi adalah pesaingan pasar yang begitu banyak dan menyebabkan omzet penjualan menjadi tidak memenuhi target. Sementara itu Hutabarat, B. (2016) memaparkan tentang kondisi pasar dunia dan dampaknya terhadap kinerja industri perkopian nasional.

Sementara itu kajian mengenai bagaimana dunia kopi masuk pada materi dalam pembelajaran belum ada ditemukan kajian yang mendalam. Materi-materi seperti ini sudah seyogyanya ada pada kurikulum di sekolah luar biasa sehingga memiliki ciri fokus terhadap pembelajaran khususnya pada materi tata boga yang akan menggiring siswa punya keahllian secara profesional dan memiliki usaha sendiri setelah menamakan bangku pendidikan.

Hal tersebut seiring dengan dukungan dari pemerintah dengan terbitnya UUD No. 8 tahun 2016 tentang penyandang disabilitas. Pada pasal 56 berbunyi pemerintah dan pemerintah daerah wajib memberikan jaminan, perlindungan, dan pendampingan kepada penyandang disabilitas untuk berwirausaha dan mendirikan badan usaha sesuai dengan ketentuan peraturan perundang-undangan. Selanjutnya pasal 60 berbunyi bahwa pemerintah, pemerintah daerah wajib memberikan pelatihan kewirausahaan kepada penyandang disabilitas yang menjalankan unit usaha mandiri. Usaha-usaha tersebut dapat mengangkat kearifan lokal pada di mana penyandang disabilitas tersebut berada.

Sementara Muspita, R., Safaruddin, S., Ardisal, A., \& Sopandi, A. A. (2018) memaparkan bahwa anak hambatan pendengaran kesulitan dalam mencari lapangan pekerjaan yang sesuai dengan kebutuhan. Dimana setelah tamat dari sekolah luar biasa anak hanya berada di rumah dan ataupun bekerja anak kesulitan dalam penyesuaian diri di tempat kerja. Akibatnya anak kembali ke sekolah dan atau menganggur di rumah. 
Berdasarkan pemaparan di atas perlu mengoptimalkan kompetensi guru dalam mengembangkan peserta didik untuk mengaktualisasikan diri yang meliputi memfasilitasi peserta didik mengembangkan berbagai potensi akademik maupun non-akademik. Potensi non-akademik dapat berupa soft skill untuk terjun ke dunia usaha sehingga dapat mandiri sesuai dengan cita-cita bangsa. Selain itu melalui pelatihan ini guru-guru memiliki kemampuan dalam menyeduh kopi dengan menerapkan teknik manual brewing. Sehingga soft skill yang dimiliki guru akan ditransfer kepada anak hambatan pendengaran pada mata pelajaran tata boga atau vocasional Sehingga hal ini akan menjadi peluang bagi anak hambatan pendengaran untuk bekerja dan bahkan membuka usaha sendiri.

\section{Metode}

Kegiatan ini diawali dengan pelaksanaan seminar yang dihadiri oleh 39 orang guru sekolah luar biasa dari berbagai kepakaran. Seminar dilakukan selama 1 hari dengan 3 pemteri dari latar belakang yang berbeda. Pemateri pertama dosen pendidikan luar biasa yang membahas tentang softskill anak hambatan pendengaran, pemateri ke dua oleh salah satu guru tataboga yang mengajar di sekolah luar biasa dengan materi macam-macam jenis minuman, dan selanjutnya pemateri ketiga adalah salah satu barista di kota Padang yang menjelaskan tentang Teknik Manual Brewing.

Tahap berikutnya adalah praktek dalam penyeduhan kopi dengan teknik manual brewing sebanyak 6 kali pertemuan dengan masing-masing 5 jam setiap pertemuannya. Praktek tersebut didampingi lansung oleh tenaga profesional dalam hal ini seorang barista dan sekaligus memiliki coffeshop di Kota Padang.

Sebelum pemberian seminar dan pelatihan, guru diberikan berupa pretest sederhana tentang wawasan guru tentang kopi dan cara penyeduhannya. Setelah praktek selesai, guru diberikan lagi berupa posttest dengan soal yang sama. Data didapatkan lalu dilakukan penyadian dengan mendeskripsikan data tersebut.

\section{Hasil dan Pembahasan}

\section{Demografi Guru}

Keterlibatan Guru dan kualifikasi guru pada kegiatan ini sangat mempengaruhi penerapan dari Teknik Manual Brewing dalam penyeduhan kopi. Guru yang ikut dalam pelatihan merupakan perwakilan dari masing-masing sekolah luar biasa se-kota Padang yang memiliki anak hambatan pendengaran yang rata-rata sudah berada di kelas tinggi. Guru yang terlibat sebanyak 10 orang dan sebagai peserta aktif.

Gambar 1 memaparkan kondisi awal dan kondisi setelah dilakukan pelatihan. Guru-guru tersebut merupakan guru yang mengajarkan tata boga. Terlihat dimana guru A pada kondisi awal hanya memiliki pemahaman tentang jenis-jenis kopi, alat penyeduhan dan teknik manual brewing dalam penyeduhan kopi dengan pemahaman 50\% dan setelah pelatihan meningkat menjadi $93 \%$.

Guru B dengan kondisi awal $62 \%$ sementara setelah pelatihan menjadi $87 \%$, guru C yaitu $56 \%$ setelah pelatihan menjadi $87 \%$, guru D $37 \%$ dan setelah pelatihan meningkat menjadi $87 \%$, guru E $43 \%$ setelah pelatihan meningkat menjadi 93\%, guru F memiliki nilai kondisi awal 56\% sementara setelah pelatihan mendapat $93 \%$, guru G kondisi awal $63 \%$ setelah pelatihan $87 \%$, guru $\mathrm{H}$ kondisi awal $31 \%$ setelah pelatihan 93\%, guru I 50\% pada kondisi awal dan mendapat skor $87 \%$ setelah melakukan pelatihan, dan selanjutnya guru $\mathrm{J}$ dengan kondisi awal $25 \%$ setelah melakukan pelatihan meningkat menjadi $87 \%$. 


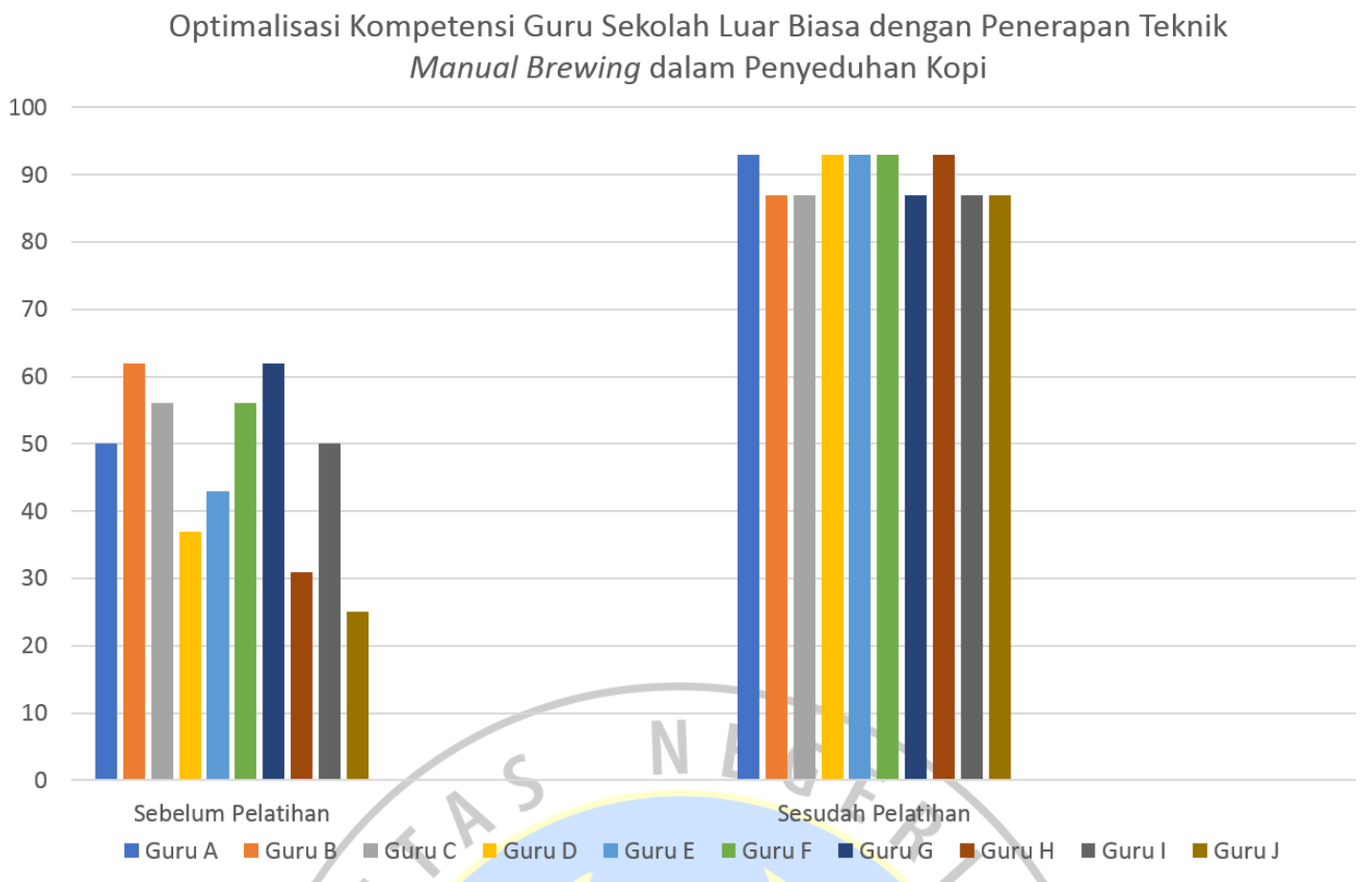

Gambar 1. Kondisi Sebelum dan Sesudah Pelatihan

Pada penyajian data figure 1 terlihat kempauan guru mengalami peningkatan dalam penyajian kopi dengan teknik manual brewing. Pada awalnya guru-guru kebanyakan hanya mengetahui penyeduhan kopi secara tradisional atau dikenal dengan kopi tubruk dan mengenal jenis kopi dengan menyebutkan beberapa merk kopi instan dan tidak mengetahui single origin dari kopi itu sendiri.

\section{Fenomena yang diajarkan}

Materi pertama yang diberikan kepada guru mengenai keterampilan bagi anak hambatan pendengaran. Pemberian materi ini bertujuan sebaga wacana dasar membuka wawasan guru-guru tentang bagaimana dengan memberikan keterampilan kepada anak hambatan pendengaran berkontribusi untuk mempersiapkan kemandirian anak hambatan pendengaran. Materi kedua tentang Tataboga dan beverage dimana materi memaparkan bahwa tataboga merupakan bagian dari keterampilan yang wajib dimiliki anak dan sesuai perkembangan minuman terkhusus minuman perangsang yakni kopi sudah menjadi kebutuhan masyarakat pada dewasa ini. Dan selanjutnya materi ketiga tentang Jenis-jenis kopi dan teknik penyeduhannya. Materi ini memberi gambaran kepada guruguru bahwa banyaknya varietas kopi dan citarasa kopi itu sendiri. Dengan ciri khas dan cita rasa kopi itu sendiri akan berkurang atau bahkan tidak muncul jika penyajiannya atau penyeduhannya tidak tepat. Sebagaimana sudah kita ketahui pemilihan teknik manual brewing dalam penyeduhan kopi adalah cara untuk mendapatkan cita rasa kopi itu sendiri. Teknik manual breeing merupakan salah satu metode dalam pengolahan kopi, memberikan inspirasi dalam berupa alur proses biji kopi sehingga mampu menampilkan ciri khas tersendiri (Hodinata, E., Kusumowidagdo, A., 2018).

Rangkaian kegiatan berikutnya adalah pelatihan. Pelatihan ini mengharapkan guru-guru belajar lansung dengan tenaga profesional dan pelaku bisnis pada dunia perkopian. Pelatihan ini dilakukan sebanyak enam kali dan setiap pertemuannya selama lima jam. Latihan yang dilakukan pertama yaitu bagaimana guru-guru mampu mengenal alat dan fungsi alat seduh manual brewing. Dengan mengetahui jenis-jenis alat seduh diharapkan guru-guru dapat menggunakannya dengan tepat pada pelatihan berikutnnya. Alat seduh manual mempermudah penikmat kopi di Indonesia karena alat yang digunakan cukup murah dan dapat menikmati ciri khas rasa kopi single origin Indonesia (Widya Lestari, E., 2016). Sehingga dapat memilih teknik manual brewing mana yang dirasa guru mampu melakukannya. Pelatihan kedua teknik pemilihan kopi dan perbedaan jenis kopi. Pelatihan ini sangat penting karena 
tidak semua jenis kopi dapat disajikan dengan teknik manual brewing. Pelatihan ketiga yaitu teknik cupping dimana teknik ini dasar untuk mengenali aroma, rasa dan ciri khusus atau cita rasa dari kopi itu sendiri. Materi keempat adalah teknik roasting dan grinder. Roasting dan grinder adalah langkahlangkah untuk menghasilkan bubuk kopi. Untuk teknik manual brewing mempunyai ukuran dan takaran tersendiri saat melakukan roasting dan grinder terhadap kopi tersebut. Alat pertama yang bersentuhan dengan biji kopi adalah penggilingan kopi. Ukuran kehalusan kopi hasil gilingan mempengaruhi penentuan rasa kopi (Widya Lestari, E., 2016). Materi kelima tentang teknik mananual brewing V60 dimana teknik ini salah satu teknik manual brewing yang banyak digemari penikmat kopi karena mampu menghasilkan karakter kopi secara baik. [pendapat orang]. Dan kegiatan berikutnya adalah tenik manual brewing menggunakan mokapot. Dimana teknik manual brewing menggunakan mokapot dapat dimanfaatkan untuk menghasilkan kopi espresso dan kombinasi kopi lainnya seperti coffee latte, cuppucino, dan lainnya. Cara ini dapat menghasilkan kopi espresso bagi yang tidak memiliki mesin espresso.

\section{Proses Pelaksanaan Kegiatan}

Gambar 2 pada kegiatan seminar yang dilakukan di salah satu sekolah di kota Padang dengan melibatkan 10 guru tata boga yang memiliki anak hambatan pendengaran se-Kota Padang dan dihadiri oleh guru lainnya sebgai partisipan dari berbagai keahlian.

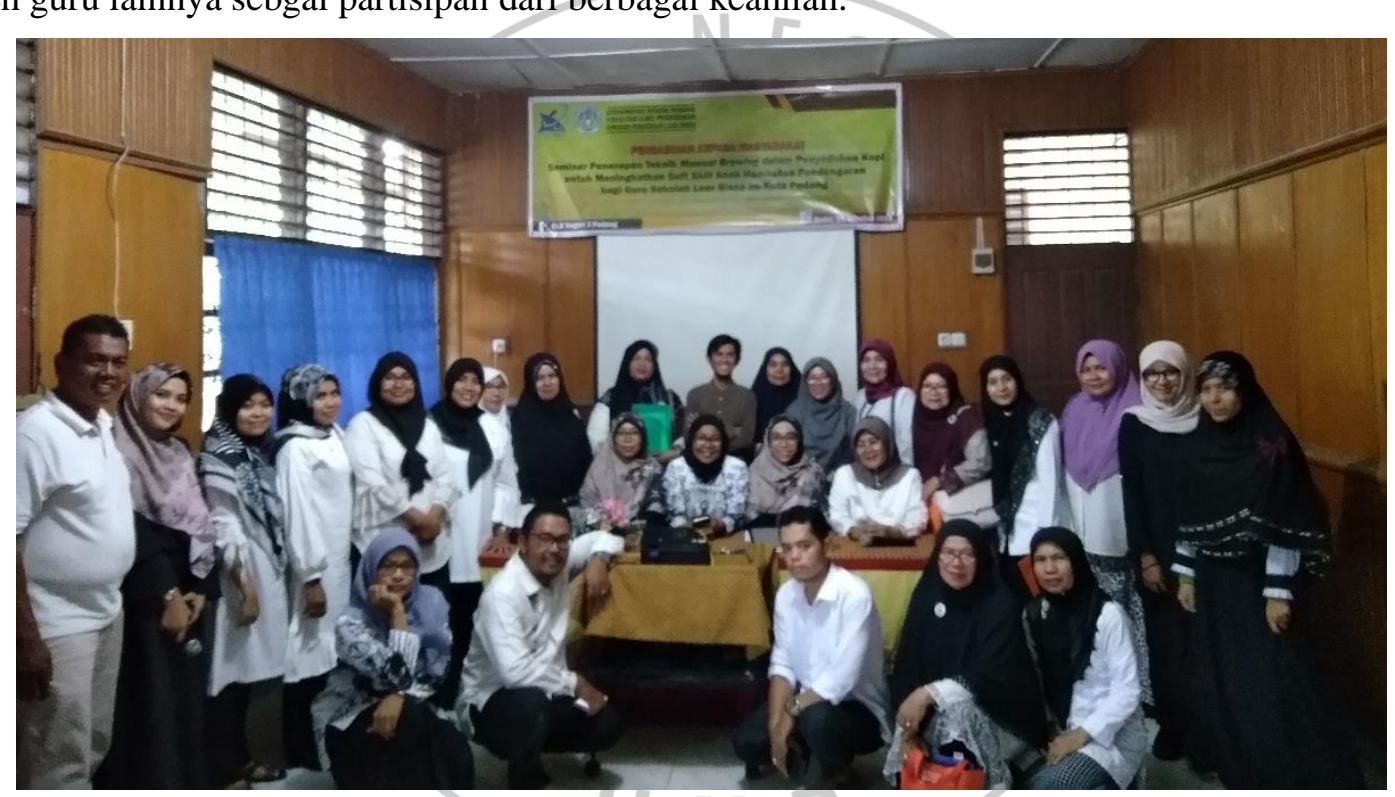

Gambar 2. Kegiatan Seminar Teknik Manual Brewing

Sementara gambar 2 terlihat seorang barista dan sekaligus pelaku usaha kopi sedang serius menjelaskan cara penyeduhan teknik manual brewing dengan alat V60. Setelah tutor menjelaskan secara bergantian guru akan menyeduh kopi sendiri dan merasakan hasil seduhannya. Selanjutnya guruguru akan bergantian mencicipi kopi hasi seduhan guru lain dan saling mengomentari kopi yang telah diseduh. 


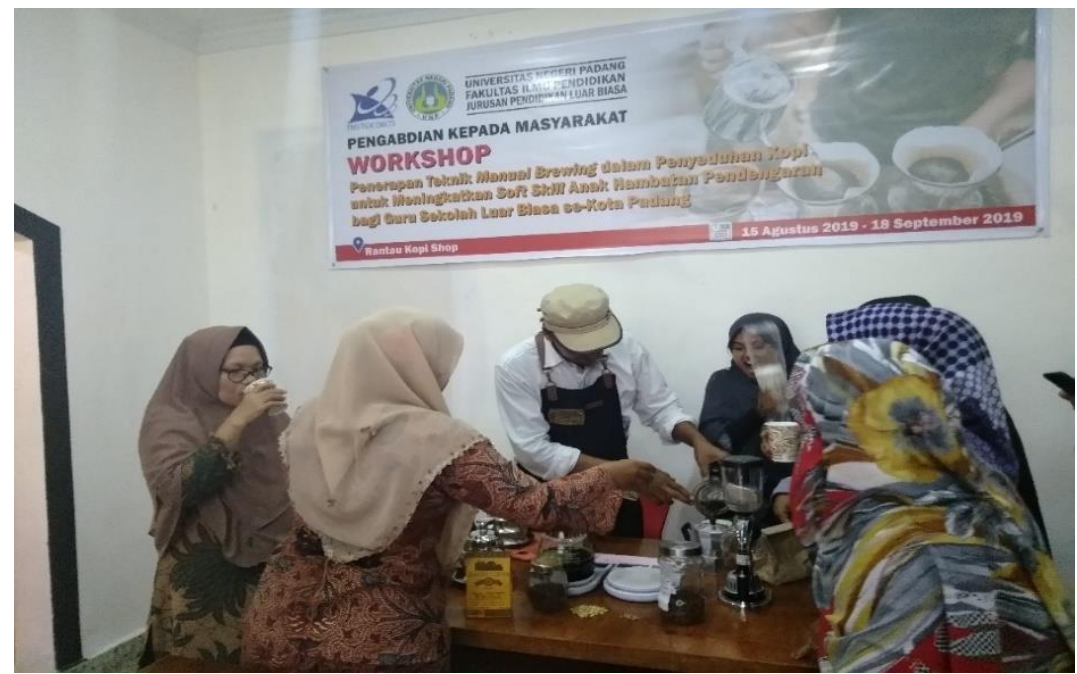

Gambar 3. Praktek penyeduhan kopi menggunakan V60

Pada pelaksaan guru-guru sangat antusias dan merasakan manfaat tersendiri dari pelatihan tersebut dan mendapatkan pengetahuan tentang kopi yang selama ini bellum diketahui guru. Seperti pernyataan guru C "Saya dapat mengetahui jenis-jenis kopi, rasa yang ada pada kopi, dan cara penyeduhan kopi" selanjutnya guru C juga berkomentar bahwa "seminar dan workshop ini akan memiliki dampak manfaat bagi anak hambatan pendengaran dan juga menjadi peluang usaha untuk kemandirian anak hambatan pendengaran". Hal tersebut juga dinyatakan oleh guru E bahwa "Pelatihan ini sangat bermanfaat sekali sehingga saya mengetahui berbagai macam rasa dalam kopi dan nantinya akan dapat diaplikasikan kepada anak hambatan pendengaran". Dan guru I juga berkomentar hal yang sama bahwa "melalui pelatihan ini menambah ilmu saya dalam penyeduhan kopi yang enak dan selama ini belum saya ketahui. Hal ini dapat saya kembangkan untuk meningkatkan soft skill anak hambatan pendengaran di tempat saya mengajar".

Selanjut guru F menyatakan "saya mendapatkan ilmu tentang budidaya kopi, berbagai macam olahan kopi, serta alat-alat yang digunakan untuk penyeduhan kopi, dimana alat-latnya sangat murah didapakan". Alat seduh manual mempermudah penikmat kopi di Indonesia karena alat yang digunakan cukup murah Indonesia (Widya Lestari, E., 2016). Dilanjutkan oleh guru J bahwa "pengalaman yang saya dapatkan sangat banyak sekali diantaranya saya bisa menyeduh kopi dengan cara yang berbeda dari biasanya, mengetahui alat berserta fungsinya dalam penyeduhan kopi, dan mengetahui berbagai macam jenis kopi". Sementara guru H memaparkan lebih detail lagi yaitu "pelatihan ini menambah wawasan saya tentang jenis-jenis kopi dan membedakan mana jenis Arabika dan mana jenis Robusta. Serta saya mengetahui cara penyeduhan kopi dengan beberapa teknik manual brewing diantaranya V60, mokapot, dan sifon".

\section{Kesimpulan}

Melalui pelatihan ini guru-guru memiliki kemampuan dalam menyeduh kopi dengan menerapkan teknik manual brewing. Sehingga soft skill yang dimiliki guru akan ditransfer kepada anak hambatan pendengaran pada mata pelajaran tataboga atau vocasional. Penerapan teknik manual brewing dalam penyeduhan kopi dirasa perlu diberikan kepada guru-guru agara dapat dipraktekkan lansung dan dimasukkan sebagai bahan ajar karena keberadaan penyandang disabilitas di Kota Padang khususnya dan Sumatera Barat pada umumnya berada pada lingkungan yang memiliki kekayaan kearifan lokal. Salah satu yang memiliki pasar yang cukup luas dan peminat yang terus-menerus adalah minuman kopi. Penyajian kopi yang terus digemari konsumen adalah dengan teknik manual brewing karena teknik ini memiliki keunikan tersendiri menciptakan cita rasa keaslian kopi itu sendiri. Sehingga hal ini akan menjadi peluang bagi anak hambatan pendengaran untuk bekerja dan bahkan membuka usaha sendiri. 


\section{Daftar Pustaka}

Everage, Laura. 2012. "Manual Brewing - The Basics". Coffee Universe, (Online), (http://coffeeuniverse.com/manual-brewing-the-basics/), Diakses 15 Februari 2016.

Hodinata, E., Kusumowidagdo, A., \& Wardhani, D. K. (2018). Perancangan Interior Hocoop (Coffee and Eatery) Dengan Tema Manual Brewing with Natural Style. KREASI, 2(2), 130-152

Hutabarat, B. (2016). Kondisi pasar dunia dan dampaknya terhadap kinerja industri perkopian nasional. Jurnal Agro Ekonomi, 22(2), 147-166.

Muspita, R., Safaruddin, S., Ardisal, A., \& Sopandi, A. A. (2018). Pembelajaran Keterampilan Membuat Ikan Bakar Bagi Anak Hambatan Pendengaran. Jurnal Pendidikan Kebutuhan Khusus, 2(2), 48-50.

Perkasa, A. G. (2018). Kontribusi Specialty Coffee Association Dalam Meningkatkan Industri Kopi di Indonesia (Studi Kasus Petani Kopi Aceh Pantan Musara). Disertasi. Perpustakaan

Triatmoko, E., Fitriadi, S., \& Gafur, A. (2016). Prospek USAha Agroindustri Kopi di Desa Jati Baru Kecamatan Astambul Kabupaten Banjar. Ziraa'ah Majalah Ilmiah Pertanian, 41(2), 188-194.

Hastuti, D. S. (2018). Kandungan Kafein pada Kopi dan Pengaruh terhadap Tubuh. Research Gate [7 November 2018].

Widya Lestari, E. (2016). Penyutradaraan Program Feature Inside My Drinks Episode: Manual Brewing Coffee. Disertasi. Institut Seni Indonesia Yogyakarta.

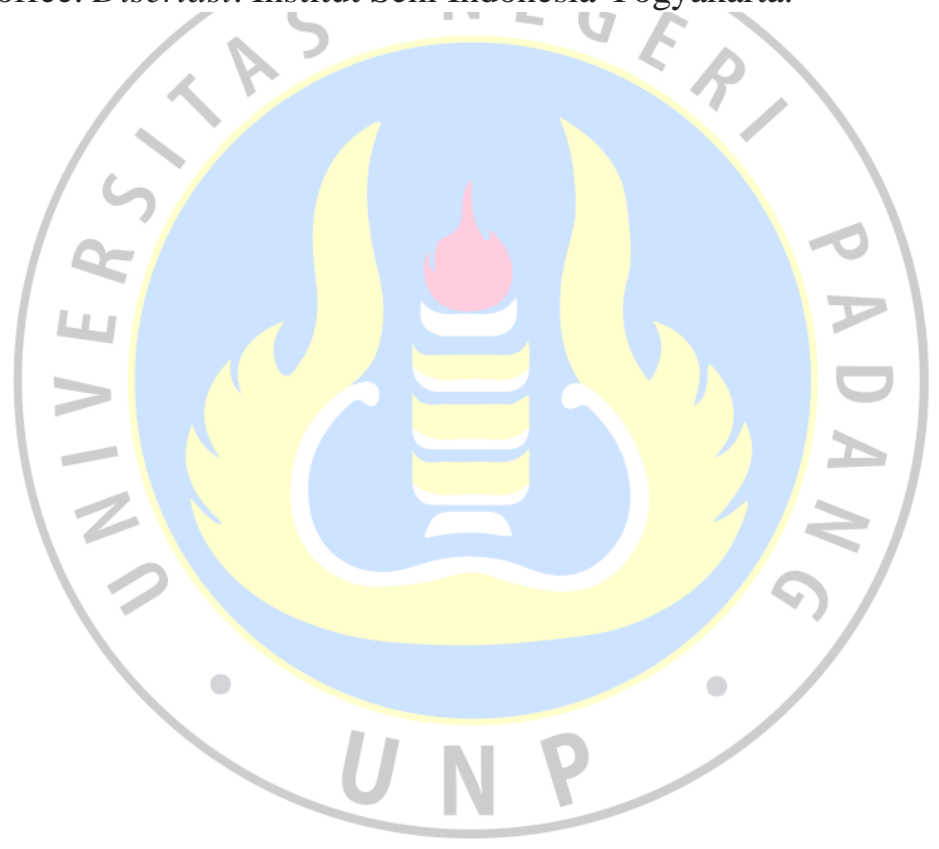

